\title{
Appraisal of Cost-Effective Return from Marigold Flower Grower in Jammu District, India
}

\author{
Raju Gupta $^{1 *}$, Pawan K. Sharma ${ }^{2}$, Ajay Kumar ${ }^{2}$, Punit Choudhary ${ }^{1}$ and Poonam Abrol ${ }^{1}$ \\ ${ }^{1}$ KVK, Jammu, ${ }^{2}$ KVK, Kathua, Sher-e- Kashmir University of Agricultural Sciences and \\ Technology, Jammu-180 009, (J\&K), India \\ *Corresponding author
}

A B S T R A C T

\begin{tabular}{|l|}
\hline K e y w o r d s \\
$\begin{array}{l}\text { Appraisal, Cost- } \\
\text { effective return, } \\
\text { Marigold, } \\
\text { Production }\end{array}$ \\
\hline Article Info \\
\hline $\begin{array}{l}\text { Accepted: } \\
\text { 26 July 2018 } \\
\text { Available Online: } \\
\text { 10 August } 2018\end{array}$ \\
\hline
\end{tabular}

Floriculture has blossomed into commercial activity with a considerable growth and a useful crop diversification option, particularly for small farmers over the past three decades. India has now emerged as second largest grower of flowers after china. In Jammu and Kashmir the practice of flower cultivation at commercial scale by individual growers is at its infancy stage in the state; however commercial cultivation is gradually increasing with boost from the state government. At present, around 300 hectares of land in the state is under cultivation of different varieties of flowers, particularly marigold, jasmine, aster, rose, chrysanthemum and tuberose. In the recent years, the state has been exporting flowers worth Rs. 2 crore annually and more than 300 people are associated with this sector. Jammu district is enriched with diverse agro climatic condition such as fertile land, suitable climate abundant water supply, low labour cost, availability of skilled man power etc., which are quite beneficial for growing a variety of flowers plant throughout the year. This paper aims to conducting study on appraisal of cost-effective return from open pollinated marigold flower production in Jammu district of Jammu and Kashmir.

\section{Introduction}

Floriculture is an important enterprise of agricultural sector in India as flowers in India are used for many purposes and in many important events like religious, parties and festivals etc. Among major flowers, marigold is one of the famous flowers of India belongs to composite family. Floriculture in recent times becomes an integral part of diversified agriculture practiced by the farmers in Jammu division of Jammu and Kashmir State.
Marigold is an important ornamental crop generally return from unit area. The recommended marigold cultivation practices are complex and cost involving which require sufficient information on the part of farmers. In garden marigold provides beautification of beds and borders. An orange pigment extracted from petals is in great demand for poultry feed. Marigold is also grown for keeping the nematode population in soil under control. Marigold is the major floricultural crop of Jammu region, grown over an area of 
240 acres. The government has also taken several initiatives to increase the share of floriculture in farmers' economy. Looking to these facts, the present study was carried out with the objective, to study the socioeconomic characteristics of the respondents and to assess the economics of marigold production in Jammu district.

\section{Materials and Methods}

The present study has been conducted in R. S. Pura block of Jammu district of Jammu and Kashmir State. This block was selected purposively as it is one of the most agriculturally active blocks of the state. The majority of farmers have diversified their farms by adopting floriculture as one of the major enterprises. In this study two villages Chouhala and Dablehar were selected purposively as there are sufficient numbers of flower growers present in these villages. Thirty respondents from each village were interviewed through convenient sampling, thus making a total sample of sixty respondents for the present study. The responses of the respondents were recorded in a pre-designed interview schedule. The statistical methods like percentage and frequency were employed for analysing the data.

\section{Results and Discussion}

\section{Frequency of respondents under different size groups}

It is evident from Table 1 that 13.33 per cent growers fall into the category of marginal farmers, as they had land holding of less than 1 hectare, twenty growers i.e. 33.33 per cent fall into the category of small farmers, as they had land holding between 1 to 2 hectares and thirty two growers i.e. 53.34 per cent fall into the category of large farmers, as they had land holdings of more than 2 hectares. It can also be seen that majority of marigold growers fall into the category of large farmers, followed by small and then marginal. This indicates that only such farmers were engaged in flower production those have more land at their disposal to diversify there cropping pattern. It is also shows that the small farmers were having less interest towards cultivation of flowers because of requirement of high input and due to labour intensive activity

\section{Socio-economic characteristics of the respondents}

The data pertaining to socio-economic characteristics have been presented in Table 2 . Which reveals that twenty five per cent of marginal farmers were having age between 36 to 50 years, fifty per cent of marginal farmers were having age between 51 to 65 years and twenty five per cent of marginal farmers were having age of more than 65 years. Similarly, fifteen per cent of small farmers belong to the age group of less than 35 years, fifty per cent of small farmers were of age between 36 to 50 years, thirty per cent of small farmers belong to age group of 51 to 65 years and five per cent of farmers were having age of more than 65 years. Also, 6.24 per cent of large farmers belong to the age group of less than 35 years, 34.38 per cent of large farmers were of age between 36 to 50 years, 46.88 per cent of large farmers belong to age group of 51 to 65 years and four per cent of farmers were having age of more than 65 years. In case of education it is evident from the table that majority i.e. 62.50 per cent of marginal farmers had education up to higher secondary level and twenty five per cent of marginal farmers were having education above graduation level. Similarly, it can be observed that ten per cent of small farmers had education below matric. Majority 70.00 per cent of small farmers had education up to higher secondary level and twenty per cent of small farmers had education above graduation level. 


\section{Table.1 Frequency of respondents under different size groups}

\begin{tabular}{l} 
Size of land holdings \\
Less than 1 hectare \\
\hline 1 -2 hectares \\
\hline More than 2 hectares \\
\hline
\end{tabular}

\begin{tabular}{|c|c|}
\hline No. of respondents & Categorized as \\
\hline $08(13.33)$ & Marginal \\
\hline $20(33.33)$ & Small \\
\hline $32(53.34)$ & Large \\
\hline 60 & \\
\hline
\end{tabular}

\begin{tabular}{|c|c|c|c|c|c|}
\hline \multicolumn{5}{|c|}{ Table.2 Socio-economic characteristics of the marigold flower growers } & \multirow{3}{*}{$\begin{array}{l}\text { Number }(\mathbf{N}=\mathbf{6 0}) \\
\text { Percent }(\mathbf{1 0 0 \%})\end{array}$} \\
\hline S. No & categories & \multicolumn{3}{|c|}{ Size of land holding } & \\
\hline \multirow[t]{5}{*}{1} & Age in years & Marginal & Small & Large & \\
\hline & less than 35 & $00(00.00)$ & $03(15.00)$ & $02(06.24)$ & $05(08.33)$ \\
\hline & $36-50$ & $02(25.00)$ & $10(50.00)$ & $11(34.38)$ & $23(38.33)$ \\
\hline & $51-65$ & $04(50.00)$ & $06(30.00)$ & $15(46.88)$ & $25(41.67)$ \\
\hline & More than 65 & $02(25.00)$ & $01(05.00)$ & $04(12.50)$ & 07 (11.67) \\
\hline \multirow[t]{4}{*}{2} & Educational level & & & & \\
\hline & Matric \& below & $01(12.50)$ & $02(10.00)$ & $04(12.50)$ & 07 (11.67) \\
\hline & Higher secondary & $05(62.50)$ & $14(70.00)$ & $19(59.38)$ & $38(63.33)$ \\
\hline & Graduation \& above & $02(25.00)$ & $04(20.00)$ & $09(28.13)$ & $15(25.00)$ \\
\hline \multirow[t]{4}{*}{3} & Land Holding & & & & \\
\hline & Small size(0-5 acres) & $07(70.00)$ & $20(60.60)$ & $15(68.18)$ & $37(61.67)$ \\
\hline & Medium size (5-10 acres) & $03(30.00)$ & $08(24.24)$ & $04(18.18)$ & $15(25.00)$ \\
\hline & $\begin{array}{l}\text { Large size of holding } \\
\text { (10 acres and above) }\end{array}$ & $\begin{array}{c}00 \\
(00.00)\end{array}$ & $\begin{array}{c}05 \\
(15.16)\end{array}$ & $\begin{array}{c}03 \\
(13.64)\end{array}$ & $\begin{array}{c}08 \\
(13.33)\end{array}$ \\
\hline \multirow[t]{4}{*}{4} & House Type & & & & \\
\hline & Kachha House & $02(16.67)$ & 05 (17.86) & $03(15.00)$ & $10(16.67)$ \\
\hline & Pucca House & $\begin{array}{c}10 \\
(83.33)\end{array}$ & $\begin{array}{c}23 \\
(82.14)\end{array}$ & $\begin{array}{c}15 \\
(75.00)\end{array}$ & $\begin{array}{c}48 \\
(80.00)\end{array}$ \\
\hline & Mansion & $\begin{array}{c}00 \\
(00.00)\end{array}$ & $\begin{array}{c}00 \\
(00.00)\end{array}$ & $\begin{array}{c}02 \\
(10.00)\end{array}$ & $\begin{array}{c}02 \\
(03.33)\end{array}$ \\
\hline \multirow[t]{3}{*}{5} & Caste & & & & \\
\hline & Upper Caste & $\begin{array}{c}10 \\
(76.93)\end{array}$ & $\begin{array}{c}22 \\
(61.11)\end{array}$ & $\begin{array}{c}08 \\
(72.73)\end{array}$ & $\begin{array}{c}40 \\
(66.67)\end{array}$ \\
\hline & Lower Caste & $\begin{array}{c}03 \\
(23.07)\end{array}$ & $\begin{array}{c}14 \\
(38.89)\end{array}$ & $\begin{array}{c}03 \\
(27.27)\end{array}$ & $\begin{array}{c}20 \\
(33.33)\end{array}$ \\
\hline \multirow[t]{5}{*}{6} & Profession & & & & \\
\hline & Farming alone & $\begin{array}{c}01 \\
(12.50)\end{array}$ & $\begin{array}{c}01 \\
(05.00)\end{array}$ & $\begin{array}{c}04 \\
(12.50)\end{array}$ & $\begin{array}{c}06 \\
(10.00)\end{array}$ \\
\hline & Farming + Government Job & $\begin{array}{c}03 \\
(37.50)\end{array}$ & $\begin{array}{c}09 \\
(45.00)\end{array}$ & $\begin{array}{c}08 \\
(25.00)\end{array}$ & $\begin{array}{c}20 \\
(33.33)\end{array}$ \\
\hline & Farming + Private Job & $\begin{array}{c}01 \\
(12.50)\end{array}$ & $\begin{array}{c}05 \\
(25.00)\end{array}$ & $\begin{array}{c}12 \\
(37.50)\end{array}$ & $\begin{array}{c}18 \\
(30.00)\end{array}$ \\
\hline & Farming + Business & $\begin{array}{c}03 \\
(37.50)\end{array}$ & $\begin{array}{c}05 \\
(25.00)\end{array}$ & $\begin{array}{c}08 \\
(25.00)\end{array}$ & $\begin{array}{c}16 \\
(26.67)\end{array}$ \\
\hline \multirow[t]{4}{*}{7} & Farm power & & & & \\
\hline & 1-2 drought animal & $\begin{array}{c}16 \\
(88.89)\end{array}$ & $\begin{array}{c}22 \\
(75.87)\end{array}$ & $\begin{array}{c}08 \\
(61.54)\end{array}$ & $\begin{array}{c}46 \\
(76.67)\end{array}$ \\
\hline & 3-4 drought animal & $\begin{array}{c}02 \\
(11.11)\end{array}$ & $\begin{array}{c}05 \\
(17.24)\end{array}$ & $\begin{array}{c}03 \\
(23.07)\end{array}$ & $\begin{array}{c}10 \\
(16.67)\end{array}$ \\
\hline & Tractor & $\begin{array}{c}00 \\
(00.00)\end{array}$ & $\begin{array}{c}02 \\
(06.89)\end{array}$ & $\begin{array}{c}02 \\
(15.39)\end{array}$ & $\begin{array}{c}04 \\
(06.66)\end{array}$ \\
\hline \multirow[t]{3}{*}{8} & Family type & & & & \\
\hline & Nuclear Family & $\begin{array}{c}05 \\
(38.47)\end{array}$ & $\begin{array}{c}15 \\
(51.73)\end{array}$ & $\begin{array}{c}08 \\
(44.44)\end{array}$ & $\begin{array}{c}28 \\
(46.67)\end{array}$ \\
\hline & Joint Family & $\begin{array}{c}08 \\
(61.53)\end{array}$ & $\begin{array}{c}14 \\
(48.27)\end{array}$ & $\begin{array}{c}10 \\
(55.56)\end{array}$ & $\begin{array}{c}32 \\
(53.33)\end{array}$ \\
\hline \multirow[t]{3}{*}{9} & Family size & & & & \\
\hline & $\begin{array}{l}\text { Small size family (Up to } 5 \\
\text { members) }\end{array}$ & $\begin{array}{c}02 \\
(22.22)\end{array}$ & $\begin{array}{c}10 \\
(33.33)\end{array}$ & $\begin{array}{c}06 \\
(30.00)\end{array}$ & $\begin{array}{c}19 \\
(31.67)\end{array}$ \\
\hline & $\begin{array}{l}\text { large size family (Above } 5 \\
\text { members) }\end{array}$ & $\begin{array}{c}07 \\
(77.78)\end{array}$ & $\begin{array}{c}20 \\
(66.67)\end{array}$ & $\begin{array}{c}14 \\
(70.00)\end{array}$ & $\begin{array}{c}41 \\
(68.33)\end{array}$ \\
\hline
\end{tabular}




\section{Table.3 Item-wise cost of open pollinated Marigold Flower Production (Rs./acre)}

\begin{tabular}{|c|c|c|c|c|}
\hline \multirow[t]{2}{*}{ Particular } & \multicolumn{3}{|c|}{ Size of land holding } & \multirow[t]{2}{*}{ Overall } \\
\hline & Marginal & Small & Large & \\
\hline Seed & $\begin{array}{l}1589.55 \\
(15.31)\end{array}$ & $\begin{array}{c}1579.27 \\
(15.12)\end{array}$ & $\begin{array}{c}1461.00 \\
(14.56)\end{array}$ & $\begin{array}{c}1543.27 \\
(15.00)\end{array}$ \\
\hline Machinery labour & $\begin{array}{c}1656.82 \\
(15.96)\end{array}$ & $\begin{array}{c}1611.75 \\
(15.43)\end{array}$ & $\begin{array}{l}1444.00 \\
(14.39)\end{array}$ & $\begin{array}{c}1570.86 \\
(15.27)\end{array}$ \\
\hline Manure & $\begin{array}{c}285.73 \\
(2.75)\end{array}$ & $\begin{array}{c}290.47 \\
(2.78)\end{array}$ & $\begin{array}{c}243.80 \\
(2.43)\end{array}$ & $\begin{array}{l}273.33 \\
(2.66)\end{array}$ \\
\hline Chemical fertilizers & $\begin{array}{c}688.37 \\
(6.63)\end{array}$ & $\begin{array}{c}710.08 \\
(6.80)\end{array}$ & $\begin{array}{c}677.33 \\
(6.75)\end{array}$ & $\begin{array}{l}691.93 \\
(6.73)\end{array}$ \\
\hline Insecticides & $\begin{array}{c}347.05 \\
(3.34)\end{array}$ & $\begin{array}{l}346.37 \\
(3.32)\end{array}$ & $\begin{array}{c}315.73 \\
(3.15)\end{array}$ & $\begin{array}{c}336.38 \\
(3.27)\end{array}$ \\
\hline Irrigation & $\begin{array}{l}56.56 \\
(0.54)\end{array}$ & $\begin{array}{l}56.57 \\
(0.54)\end{array}$ & $\begin{array}{l}51.00 \\
(0.51)\end{array}$ & $\begin{array}{l}54.71 \\
(0.53)\end{array}$ \\
\hline Human Labour & $\begin{array}{l}1090.49 \\
(10.50)\end{array}$ & $\begin{array}{c}1092.71 \\
(10.46)\end{array}$ & $\begin{array}{l}1053.00 \\
(10.49)\end{array}$ & $\begin{array}{c}1078.73 \\
(10.49)\end{array}$ \\
\hline Interest on variable cost @ 12\% & $\begin{array}{c}157.38 \\
(1.52)\end{array}$ & $\begin{array}{c}170.62 \\
(1.63)\end{array}$ & $\begin{array}{c}171.44 \\
(1.62)\end{array}$ & $\begin{array}{l}166.48 \\
(1.62)\end{array}$ \\
\hline Total Variable Cost & $\begin{array}{c}5871.95 \\
(56.55)\end{array}$ & $\begin{array}{c}5857.84 \\
(56.08)\end{array}$ & $\begin{array}{c}5417.30 \\
(53.98)\end{array}$ & $\begin{array}{c}5715.69 \\
(55.56)\end{array}$ \\
\hline Estimated Rental Value & $\begin{array}{c}3600 \\
(34.67)\end{array}$ & $\begin{array}{c}3600 \\
(34.46)\end{array}$ & $\begin{array}{c}3600 \\
(34.99)\end{array}$ & $\begin{array}{c}3600 \\
(34.99)\end{array}$ \\
\hline Land revenue & $\begin{array}{c}50 \\
(0.48)\end{array}$ & $\begin{array}{c}50 \\
(0.48)\end{array}$ & $\begin{array}{c}50 \\
(0.49)\end{array}$ & $\begin{array}{c}50 \\
(0.49)\end{array}$ \\
\hline Depreciation on implements & $\begin{array}{c}752 \\
(7.24)\end{array}$ & $\begin{array}{c}826 \\
(7.91)\end{array}$ & $\begin{array}{c}855 \\
(7.88)\end{array}$ & $\begin{array}{l}811.00 \\
(7.88)\end{array}$ \\
\hline Interest on fixed cost @ 10\% & $\begin{array}{l}110.05 \\
(1.06)\end{array}$ & $\begin{array}{l}111.90 \\
(1.07)\end{array}$ & $\begin{array}{c}112.625 \\
(1.08)\end{array}$ & $\begin{array}{l}111.52 \\
(1.08)\end{array}$ \\
\hline Total Fixed Cost & $\begin{array}{c}4512.05 \\
(43.45)\end{array}$ & $\begin{array}{c}4587.90 \\
(43.92)\end{array}$ & $\begin{array}{c}4617.63 \\
(46.02)\end{array}$ & $\begin{array}{c}4572.52 \\
(44.44)\end{array}$ \\
\hline TOTAL COST & $\begin{array}{l}10384.00 \\
(100.00)\end{array}$ & $\begin{array}{c}10445.74 \\
(100.00)\end{array}$ & $\begin{array}{c}10034.93 \\
(100.00)\end{array}$ & $\begin{array}{c}10288.21 \\
(100.00)\end{array}$ \\
\hline
\end{tabular}

\section{Table.4 Yield and Economic Returns from open pollinated Marigold (per acre)}

\begin{tabular}{|l|}
\multicolumn{1}{|c|}{ Particular } \\
\hline Yield (kg) \\
\hline Price (Rs.) \\
\hline Gross Return (Rs.) \\
\hline Total Cost (Rs.) \\
\hline Net Return (Rs.) \\
\hline B:C Ratio \\
\hline
\end{tabular}

\begin{tabular}{|c|c|c|c|}
\hline \multicolumn{3}{|c|}{ Size of land holding } & Overall \\
\hline Marginal & Small & Large & \\
\hline 2180.33 & 2173.00 & 2343.81 & 2285.64 \\
\hline 21.22 & 21.24 & 21.84 & 21.43 \\
\hline 46266.67 & 46154.52 & 51188.81 & 48988.88 \\
\hline 10384.00 & 10445.74 & 10034.93 & 10288.21 \\
\hline 35882.67 & 35708.78 & 41153.88 & 38700.67 \\
\hline 4.46 & 4.42 & 5.10 & 4.76 \\
\hline
\end{tabular}

Also, 11.67 per cent of large farmers had education below matric, 63.33 per cent of large farmers had education up to higher secondary level and twenty five per cent of large farmers were having education above graduation level. It is very important finding that all the respondents were educated with maximum number of respondents having 
education at higher secondary level. Majority i.e.61.67 per cent farmers possessed small size of land holding followed by middle size of land holing i.e. 25.00 per cent and large size of holding i.e. 13.33 per cent respectively. The data presented the table reveals that majority i.e. 80.00 and 66.67 percent of farmers having pucca house and belongs to upper caste in all the size of land holding Sharma et al., (2005) and Singh et al., (2010) also lending support to the present finding.

It is evident from the table that 37.50 per cent of marginal farmers engaged both in 'farming + government job', and 'farming + business'. Similarly, it can be seen that 45.00 per cent of small farmers engaged in 'farming + government job'. The majority of respondents were found to be dependent on both 'farming and private jobs', followed by respondents dependent on both 'farming and government jobs'. While majority i.e.76.67 per cent of the respondent were having 1-2 drought animals followed by 53.33 per cent of the respondent having joint family and majority i.e. 68.33 per cent having large size family (above 5 members). An agriculture operation depends upon working labour available in each family. Generally medium and big family size will have more labour force when compared to small family; this finding is supported by Manjula (2003).

\section{Item-Wise Cost of Open pollinated Marigold Production (Rs./acre)}

The cost of cultivation of open pollinated marigold in the study area has been presented in Table 3. The variable cost of open pollinated marigold production was estimated to be Rs. 5871.95, Rs. 5857.84 and Rs. 5417.30 for marginal, small and large farms respectively. Similarly, the fixed cost of open pollinated marigold production was estimated to be Rs. 4512.05, Rs. 4587.90 and Rs.
4617.63 for marginal, small and large farms respectively. The total cost of open pollinated marigold production was found to be Rs. 10384.00, Rs. 10445.74 and Rs. 10034.93 for marginal, small and large farms respectively. Among the total variable cost of open pollinated marigold, on machinery labour constituted the largest share, followed by cost of seed and cost of human labour. It can be concluded that the variable cost of open pollinated marigold production decreases with increase in size of holding and the fixed cost increases with increase in size of holding. The total cost however does not show any specific pattern with increase in size of the farm.

\section{Yield and Economic Returns from open pollinated Marigold (per acre)}

The yield and returns from open pollinated marigold under three selected categories in the study area has been presented in Table 4 . The table reveals that yield of open pollinated marigold varies from Rs. 2180.33; Rs.2173 \& Rs.2343.81 for marginal, small and large farms respectively. The gross return was highest in case of large farms (Rs. 51188.81) followed by marginal farms (Rs. 46266.67) and small farms (Rs. 46154.52). The net return was also highest in case of large farms (Rs. 41153.88) followed by marginal farms (Rs. 35882.67) and small farms (Rs. 35708.78). The B: C ratio was also highest in case of large farms (5.10) followed by marginal farms (4.46) and small farms (Rs. 4.42). The overall yield of open pollinated marigold was $2285.64 \mathrm{~kg}$ per acre and net return was Rs. 38700.67.

It can be concluded that majority of marigold growers having large farming community followed by small and marginal. This indicates that the resource rich farmers having all types of facilities were actively engaged in marigold flowers cultivation. Majority of the farmers having pucca houses and belongs to 
upper caste. It can also be conclude that variable cost of open pollinated marigold production decreases with increases in size of holding and the fixed cost increase in size of holding. The gross return and net return was highest in case of large farmers followed by marginal and small farmers. It is also observed that there is further need to educate the farmers for adoption of improved technologies so that resource poor farmers could improved their livelihood and diversify their farming situation.

\section{References}

Jehanzeb, Khan, A. and Hussain, A. 2015. The marketing and cost-benefit analysis of floriculture in the rural areas of peshawar: A case study of Bazid Khel. City University Research Journal, 5(1): 49-63.

Manjula, N. (2003). An analysis of Krishiprashasthi awardee farmers and their influence on the neighboring farmers. M.Sc. (Ag) Thesis, University of Agriculture Sciences, Dharwad, Karnataka (India)

Mathivanan, B. (2013. A study on rose cultivation and marketing pattern in HOSUR Taluk, Journal of Exclusive Management Science, 2(12): 1-9.

Mou, N.H. (2012). Profitability of flower production and marketing System of Bangladesh. Bangladesh J. Agril. Res. 37(1): 77-95.

Omar, I, Chowdhury, M.I. \& Islam, T. Islam, R. Islam, M. (2014). Marketing Efficiency and Post-Harvest Loss of Flower in Bangladesh, IOSR Journal of Business and Management, 16(1): 4551.

Sharma, A; M.K. Khore and L.N. Sharma (2005). Adoption of arm and home innovations by tribal farm Woman. Madhya. J. Ext. Edu. 8(1): 1-3.

Singh and Upadhyaya. (2007). "Exploring floriculture potential. Indian Horticulture, Sept-Oct 2007 Vol. 52: 6.

\section{How to cite this article:}

Raju Gupta, Pawan K. Sharma, Ajay Kumar, Punit Choudhary and Poonam Abrol. 2018. Appraisal of Cost-Effective Return from Marigold Flower Grower in Jammu District, India. Int.J.Curr.Microbiol.App.Sci. 7(08): 4586-4591. doi: https://doi.org/10.20546/ijcmas.2018.708.483 